\title{
FAKTOR YANG BERHUBUNGAN DENGAN ANGKA KUMAN UDARA DI SD NEGERI KECAMATAN BATURRADEN
}

\author{
Olivia Anggraeni Yuliarti' ${ }^{1)}$, Tri Cahyono ${ }^{1)}$, Tri Marthy Mulyasari' ${ }^{1)}$ \\ Poltekkes Kemenkes Semarang
}

\begin{abstract}
Abstrak
Sekolah sebagai sarana pendidikan formal di Negeri ini, sudah sepatutnya menjadi tempat yang nyaman untuk belajar, selain itu sekolah juga dapat menjadi ancaman penularan penyakit jika tidak dikelola dengan baik. Metode yang digunakan observasional, pendekatan analitik cross sectional. Populasi 26 ruang, sampel 12 ruang kelas. Variabel bebas adalah suhu, kelembapan, pencahayaan, kepadatan hunian, dan perilaku penghuni.Variabel terikat adalah angka kuman udara dan variabel pengganggu adalah kecepatan angin, arah angin, frekuensi pembersihan, dan frekuensi penggunaan desinfektan.Analisis data menggunakanuji regresi sederhana dan uji regresi berganda. Hasil penelitian menunjukan rata-rata suhu $\left(28,11^{\circ} \mathrm{C}\right)$, kelembapan $(75,59 \%)$, pencahayaan $(320,45 \mathrm{lux})$, kepadatan hunian $\left(2,12 \mathrm{~m}^{2} /\right.$ orang), perilaku penghuni 2 ruang kelas tidak aktif, 7 ruang kelas cukup aktif, 3 ruang kelas aktif, angka kuman udara $\left(1685,33 \mathrm{CFU} / \mathrm{m}^{3}\right)$, kecepatan angin $(0,0083 \mathrm{~m} / \mathrm{s})$, arah angin $\left(176,83^{\circ}\right)$, frekuensi pembersihan $(1 \mathrm{kali} / \mathrm{hari})$, dan frekuensi penggunaan desinfektan (0kali/hari). Faktor yang berhubungan yaitu suhu $(p=0,15)$, kelembapan $(p=0,54)$, pencahayaan $(\mathrm{p}=0,85)$, kepadatan hunian $(\mathrm{p}=0,22)$, dan perilaku penghuni $(\mathrm{p}=0,20)$. Kesimpulan penelitian ini adalah faktor yang memiliki hubungan paling signifikan dengan angka kuman udara yaitu suhu, kelembaban, dan pencahayaan $(\mathrm{p}=0,09)$. Peneliti menyarankan perlu adanya ketersediaan ventilasi, kipas angin, exhauster, dan gorden.
\end{abstract}

Kata Kunci : Angka Kuman Udara, Sekolah Dasar, Kesehatan Lingkungan

\begin{abstract}
School as a means of formal education in this country, should be a comfortable place to study, besides that school can also be a threat of disease transmission if not managed properly. The method used was observational, cross sectional analytic approach. Population 26 rooms, and sample 12 classrooms. Independent variable is temperature, humidity, lighting, occupancy density, and occupant behavior. Dependent variable is the number of airborne germs, and confounding variable is wind speed, wind direction, cleaning frequency, and frequency of disinfectant use. Data analysis used a simple regression test and multiple regression test. The results showed average temperature $\left(28,11^{\circ} \mathrm{C}\right)$, humidity $(75,59 \%)$, lighting $(320,45$ lux $)$, occupancy density (2,12 $\mathrm{m}^{2} /$ person), occupant behavior 2 inactive classrooms, 7 spaces quite active class, 3 active classrooms, the number of airborne germs $\left(1685,33 \mathrm{CFU} / \mathrm{m}^{3}\right)$, wind speed $(0,0083 \mathrm{~m} / \mathrm{s})$, wind direction $\left(176,83^{\circ}\right)$, cleaning frequency (1 times/day), and frequency of use disinfectant (0 times/day). Related factors are temperature $(p=0,15)$, humidity $(p=0,54)$, lighting $(p=0,85)$, occupancy density $(p=0,22)$, and occupant behavior $(p=0,20)$. The conclusion of this study is that the factors that have the most significant relationship with the number of airborne germs are temperature, humidity, and lighting $(p=0.09)$. Researchers suggest the need for ventilation, fans, exhauster and curtains.
\end{abstract}

Keywords : The Number of Airborne Germs, Elementary School, Environmental Health 


\section{Pendahuluan}

Pemerintah, pemerintah daerah dan masyarakat menjamin ketersediaan lingkungan yang sehat dan tidak mempunyai risiko buruk bagi kesehatan (UU RI Nomor 36 Tahun 2009). Lingkungan sehat mencangkup lingkungan pemukiman, tempat kerja, tempat rekreasi, serta tempat dan fasilitas umum. Sekolah sebagai sarana pendidikan formal di Negeri ini, sudah sepatutnya menjadi tempat yang nyaman untuk belajar (Rr. Sumiyati, 2015, h.2). Sekolah selain berfungsi sebagai tempat pembelajaran juga dapat menjadi ancaman penularan penyakit bagi anak jika tidak dikelola dengan baik (Nadia, 2012).

Usaha peningkatan kesehatan lingkungan di sekolah merupakan salah satu program Usaha Kesehatan Sekolah/Madrasah (UKS/M) yang bertujuan untuk meningkatkan mutu pendidikan dan prestasi belajar peserta didik dengan meningkatkan perilaku hidup bersih dan sehat serta menciptakan lingkungan pendidikan yang sehat, sehingga memungkinkan pertumbuhan dan pekembangan yang harmonis peserta didik (Peraturan Bersama Mendikbud Nomor 6/X/PB/2014, Menkes Nomor 73 Tahun 2014, Menteri Agama Nomor 41 Tahun 2014 Menteri Dalam Negeri RI Nomor 81 Tahun 2014).

Menurut Tri Cahyono (2017, h.65) pencemaran udara yaitu adanya gas, partikulat cair, padatan, energi, atau komponen lain yang melebihi batas tertinggi atau terendah, atau yang seharusnya bahan ada namun tidak ada atau sebaliknya.Lokasi pencemaran udara digolongkan menjadi tiga yaitu emisi, ambient, dan udara ruang.

Menurut Esi Lisyatuti (2010, h.2-3) Udara dalam ruang atau indoor air menurut NHMRC (National Health Medical Research Council) adalah udara dalam ruang gedung (rumah, sekolah, restoran, hotel, rumah sakit, perkantoran) yang ditempati sekelompok orang dengan tingkat kesehatan yang berbeda-beda selama minimal satu jam. Menurut EPA (Environmental Protection Agency of America) kualitas udara dalam ruangan 2-5 kali lebih buruk daripada udara di luar. Parameter udara terbagi menjadi tiga yaitu parameter fisik udara, kimia udara, dan mikrobiologi udara. Parameter mikrobiologi udara yang sering digunakan adalah angka kuman udara, bersifat total meliputi semua kuman yang ada di udara (Tri Cahyono, 2017).

Menurut penelitian Wulan Cendana Arum (2016, h.42) di ruang kelas R221 Jurusan Kesehatan Lingkungan Politeknik Kesehatan Kemenkes Semarang hasil pemeriksaan angka kuman udara di pagi hari sebesar 11167 koloni $/ \mathrm{m}^{3}$, siang hari sebesar $13167 \mathrm{koloni} / \mathrm{m}^{3}$, dan sore hari sebesar $12167 \mathrm{koloni} / \mathrm{m}^{3}$. Rina Febriani (2017, h.89) rata-rata angka kuman udara di gedung R2 Jurusan Kesehatan Lingkungan Politeknik Kesehatan Kemenkes Semarang sebesar 189,50 koloni/jam/feet ${ }^{2}$. Hadita Deni Ayu Puspitasari (2018, h.42) di ruang kelas R226, R221, R222 Jurusan Kesehatan Lingkungan Politeknik Kesehatan Kemenkes Semarang rata-rata angka kuman udara di R226 didapatkan hasil 331,5 koloni/jam/feet ${ }^{2}, \quad$ R221 sebesar 433 koloni/jam/feet ${ }^{2}$, dan R222 sebesar 355,5 koloni/jam/feet ${ }^{2}$.

Menurut Tri Cahyono (2017 h.198-200) secara spesifik kondisi yang menyebabkan kuman di udara jumlahnya banyak karena kondisi parameter fisik dan kimia udara seperti radiasi, suhu, kelembaban, pencahayaan, dan desinfektan atau antiseptic; kondisi mikroorganisme; antropogenik meliputi kegiatan, kepadatan hunian, dan personal hygiene; serta sarana dan prasaran bangunan meliputi ventilasi, AC, linen, dan perabot.

Berdasarkan pengukuran angka kuman udara oleh peneliti di ruang kelas $2 \mathrm{~A}$, ruang kelas 4A, dan ruang kelas 6A di SDN Karangmangu diperoleh hasil pada ruang kelas 2A sebesar $3.066 \mathrm{CFU} / \mathrm{m}^{3}$, ruang kelas $4 \mathrm{~A}$ sebesar $2.337 \mathrm{CFU} / \mathrm{m}^{3}$ serta pada ruang kelas 6A sebesar $2.467 \mathrm{CFU} / \mathrm{m}^{3}$, sedangkan jika dibandingkan dengan Peraturan Menteri Kesehatan RI Nomor 48 Tahun 2016hasil angka kuman udara tersebut tidak memenuhi persyaratan.

Atas dasar latar belakang diatas, maka penulis tertarik untuk melakukan penelitian dengan judul "Faktor yang Berhubungan dengan Angka Kuman Udara di SD Negeri Karangmangu Kecamatan Baturraden Kabupaten Banyumas Tahun 2019".

Tujuan penelitian ini adalah Menganalisis faktor yang berhubungan dengan angka kuman udara di SD Negeri Karangmangu Kacamatan Baturraden Kabupaten Banyumas Tahun 2019.

\section{Bahan dan Metode}

Jenis penelitian ini merupakan suatu penelitian observasional dengan pendekatan analitik cross sectional. Populasi dalam penelitian ini adalah semua ruangan di SD Negeri Karangmangu sebanyak 26 ruangan, dan jumlah sampel sebanyak 12 ruang kelas.

Variabel bebas yaitu variabel yang berpengaruh atau yang menyebabkan berubahnya variabel terikat dan merupakan variabel pengaruh yang paling utama. Variabel bebas dalam penelitian ini adalah suhu, kelembapan, pencahayaan, kepadatan hunian, dan perilaku penghuni. Variabel terikat yaitu 
variabel yang diduga nilainya akan berubah karena adanya pengaruh dari variabel bebas. Variabel terikat dalam penelitian ini adalah angka kuman udara. Variabel pengganggu adalah suatu variabel bebas (selain dari penyebab yang dihipotesiskan) yang mempunyai atau dapat menimbulkan pengaruh pada variabel tidak bebas, tetapi penyebarannya secara sistematik berkaitan dengan variabel penyebab yang dihipotesiskan. Variabel pengganggu dalam penelitian ini adalah kecepatan angin, arah angin, frekuensi pembersihan dan frekuensi penggunaan desinfektan.

Instrumen penelitian ini merupakan alat untuk mengumpulkan data dari suatu penelitian. Instrumen penelitian adalah alat atau fasilitas yang digunakan oleh peneliti dalam meneliti dan mengumpulkan data agar penelitiannya lebih mudah dan hasilnya akan lebih baik dalam arti tepat, lengkap, sistematis sehingga lebih mudah untuk diolah. Instrumen yang digunakan adalah thermometer, hygrometer, luxmeter, cawan petri, inkubator, media PCA (Plant Count Agar), anemometer, kompas, tali, dan kuisioner. Hasil dianalisis dengan menggunakan software analisis data yang terdiri dari analisis univariate, analisis bivariate menggunakan uji regresi sederhana dan analisis multivariate menggunakan uji regresi berganda.

\section{Hasil dan Pembahasan}

a. Univariate

1. Suhu

Tabel 3.1 Hasil Pengukuran Suhu

\begin{tabular}{cccc}
\hline No. & Ruang Kelas & Suhu $\left({ }^{\circ} \mathrm{C}\right)$ & Kategori \\
\hline 1. & $1 \mathrm{~A}$ & 26,33 & TMS \\
\hline 2. & $1 \mathrm{~B}$ & 26,00 & MS \\
\hline 3. & $2 \mathrm{~A}$ & 26,67 & TMS \\
\hline 4. & 2B & 28,16 & TMS \\
\hline 5. & $3 \mathrm{~A}$ & 29,00 & TMS \\
\hline 6. & $3 \mathrm{~B}$ & 27,66 & TMS \\
\hline 7. & $4 \mathrm{~A}$ & 29,00 & TMS \\
\hline 8. & $4 \mathrm{~B}$ & 28,67 & TMS \\
\hline 9. & $5 \mathrm{~A}$ & 28,50 & TMS \\
\hline 10. & $5 \mathrm{~B}$ & 28,83 & TMS \\
\hline 11. & $6 \mathrm{~A}$ & 30,00 & TMS \\
\hline 12. & $6 \mathrm{~B}$ & 28,50 & TMS \\
\hline
\end{tabular}

Keterangan : TMS (Tidak Memenuhi Syarat)

MS (Memenuhi Syarat)

Pengukuran suhu dilakukan pada 12 ruang kelas dengan menggunakan thermometer air raksa, hasil pengukuran menunjukkan terdapat 11 ruang kelas $(91,66 \%)$ tidak memenuhi syarat dan 1 ruang kelas $(8,34 \%)$ memenuhi syarat. Suhu dikatakan memenuhi syarat menurut Peraturan Menteri Kesehatan RI Nomor 48 tahun 2016 yaitu berkisar $23-26^{\circ} \mathrm{C}$.

Menurut penelitian Vita Wiana Budi Cahya (2016) menyatakan bahwa kondisi suhu ruang yang terlalu rendah dapat mengakibatkan kedinginan sehingga terjadi penurunan kemampuan beraktifitas dan dapat menyebabkan gangguan kesehatan yaitu hypothermia sedangkan suhu ruang yang tinggi dapat mengakibatkan kepanasan dan tubuh berkeringan, sehingga mengakibatkan aktivitas terganggu juga. Suhu yang tinggi dapat menyebabkan dehidrasi sampai dengan heat stroke. Kondisi di lapangan terdapat 11 ruang kelas $(91,66 \%)$ yang tidak memenuhi syarat dikarenakan setiap ruang kelas memperoleh cahaya matahari yang cukup banyak sehingga mengakibatkan kenaikan suhu pada ruangan. Ketersediaan ventilasi yang baik dapat mengakibatkan pertukaran udara yang baik pula di dalam ruang kelas, penambahan kipas atau bisa juga dengan exhauster dapat membantu pengaturan suhu ruangan.

2. Kelembapan

Tabel 3.2 Hasil Pengukuran Kelembapan

\begin{tabular}{cccc}
\hline No. & $\begin{array}{c}\text { Ruang } \\
\text { Kelas }\end{array}$ & $\begin{array}{c}\text { Kelembapan } \\
(\%)\end{array}$ & Kategori \\
\hline 1. & 1A & 80,00 & TMS \\
\hline 2. & 1B & 79,66 & TMS \\
\hline 3. & $2 \mathrm{~A}$ & 79,00 & TMS \\
\hline 4. & 2B & 73,00 & TMS \\
\hline 5. & $3 \mathrm{~A}$ & 76,67 & TMS \\
\hline 6. & $3 \mathrm{~B}$ & 78,50 & TMS \\
\hline 7. & $4 \mathrm{~A}$ & 74,00 & TMS \\
\hline 8. & $4 \mathrm{~B}$ & 75,67 & TMS \\
\hline 9. & $5 \mathrm{~A}$ & 73,34 & TMS \\
\hline 10. & $5 \mathrm{~B}$ & 73,34 & TMS \\
\hline 11. & $6 \mathrm{~A}$ & 72,00 & TMS \\
\hline 12. & $6 \mathrm{~B}$ & 72,00 & TMS
\end{tabular}

Keterangan : TMS (Tidak Memenuhi Syarat) MS (Memenuhi Syarat)

Pengukuran kelembapan di 12 ruang kelas menggunakan hygrometer menunjukkan semua ruang kelas (100\%) tidak memenuhi syarat. Menurut Peraturan Menteri Kesehatan RI Nomor 48 Tahun 2016, kelembapan dikatakan memenuhi syarat yaitu berkisar 40-60\%.

Penelitian Indah Denas Tiarawati (2011, h.64) menyebutkan bahwa kelembapan ruangan 
diatas 60,00\% dapat menyebabkan berkembangbiaknya organisme pathogen maupun organisme yang bersifat allergen. Menurut Stetzenbach dalam penelitian Indah Denas Tiarawati (2011, h.66) disebutkan bahwa Micrococcus dan Staphylococcus spp. merupakan bakteri yang sering ditemukan terisolasi di udara, hal tersebut terkait juga dengan kehadirannya pada membrane mukosa hidung dan mulut, kulit, pakaian, dan rambut penghuni ruang. Fakta di lapangan menunjukkan kelembapan yang tercatat pada ruang kelas melebihi standard, untuk itu perlu adanya penambahan exhauster sehingga apabila kelembapan tinggi exhauster dapat menarik udara keluar dan juga sebaliknya kelembapan rendah maka exhauster dapat menarik udara dari luar.

3. Pencahayaan

Hasil pengukuran pencahayaan di 12 ruang kelas menunjukkan 9 ruang kelas $(75,00 \%)$ tidak memenuhi syarat dan 3 ruang kelas $(25,00 \%)$ memenuhi syarat. Pencahayaan ruang kelas yang memenuhi syarat menurut Keputusan Menteri Kesehatan RI Nomor 1429 Tahun 2006 yatu berkisar 200-300 lux.

Tabel 3.3 Hasil Pengukuran Pencahayaan

\begin{tabular}{cccc}
\hline No. & $\begin{array}{c}\text { Ruang } \\
\text { Kelas }\end{array}$ & $\begin{array}{c}\text { Pencahayaan } \\
(\text { lux })\end{array}$ & Kategori \\
\hline 1. & 1A & 415,00 & TMS \\
\hline 2. & 1B & 210,50 & MS \\
\hline 3. & 2A & 133,50 & TMS \\
\hline 4. & 2B & 105,00 & TMS \\
\hline 5. & 3A & 618,50 & TMS \\
\hline 6. & 3B & 440,50 & TMS \\
\hline 7. & 4A & 194,00 & TMS \\
\hline 8. & 4B & 234,00 & MS \\
\hline 9. & 5A & 193,00 & TMS \\
\hline 10. & 5B & 268,50 & MS \\
\hline 11. & $6 \mathrm{~A}$ & 667,50 & TMS \\
\hline 12. & $6 B$ & 365,50 & TMS \\
\hline Keteran
\end{tabular}

Keterangan : TMS (Tidak Memenuhi Syarat) MS (Memenuhi Syarat)

Keadaan ruang kelas dilengkapi jendela sehingga cahaya dapat dengan bebas masuk ke dalam ruangan, ruang kelas juga dilengkapi dengan sumber cahaya buatan yaitu lampu, cuaca pada saat dilakukan pengukuran panas sehingga intensitas cahaya matahari masuk ke dalam ruang kelas banyak sehingga pencahayaan di ruang kelas sangat terang yang mengakibatkan melebihi dari batas yang dipersyaratkan. Di setiap ruang kelas perlu difasilitasi gorden untuk mengurangi pancaran sinar matahari yang masuk ke dalam ruang kelas serta penanaman pohon rindang disekitar ruang kelas, untuk ruang kelas $2 \mathrm{~A}$ dan $2 \mathrm{~B}$ merupakan ruang kelas yang paling rendah tingkat pencahayaanya dapat dibantu dengan cara penambahan lampu neon sebanyak 4 buah.

4. Kepadatan Hunian

Tabel 3.4 Hasil Pengukuran Kepadatan Hunian

\begin{tabular}{ccccc}
\hline $\begin{array}{c}\text { Ruang } \\
\text { Kelas }\end{array}$ & $\begin{array}{c}\text { Luas } \\
\text { Ruangan } \\
\left(\mathrm{m}^{2}\right)\end{array}$ & $\begin{array}{c}\text { Jumlah } \\
\text { Penghuni } \\
(\text { orang })\end{array}$ & $\begin{array}{c}\text { Kepadatan } \\
\text { Hunian } \\
\left(\mathrm{m}^{2} / \text { orang }\right)\end{array}$ & Ket \\
\hline 1A & 54,00 & 16 & 3,37 & MS \\
\hline 1B & 52,56 & 17 & 3,09 & MS \\
\hline 2A & 49,68 & 23 & 2,16 & MS \\
\hline 2B & 47,60 & 23 & 2,06 & MS \\
\hline 3A & 51,10 & 25 & 2,04 & MS \\
\hline 3B & 51,10 & 27 & 1,89 & TMS \\
\hline 4A & 51,10 & 28 & 1,82 & TMS \\
\hline 4B & 51,10 & 26 & 1,96 & TMS \\
\hline 5A & 51,48 & 29 & 1,77 & TMS \\
\hline 5B & 45,56 & 29 & 1,57 & TMS \\
\hline 6A & 56,00 & 32 & 1,75 & TMS \\
\hline 6B & 56,00 & 28 & 2,00 & MS \\
\hline
\end{tabular}

Keterangan : TMS (Tidak Memenuhi Syarat) MS (Memenuhi Syarat)

Pengukuran kepadatan hunian diperoleh dari hasil pembagian luas ruangan dibagi dengan jumlah penghuni, dari 12 ruang kelas terdapat 6 ruang kelas $(50,00 \%)$ tidak memenuhi syarat, dan 6 ruang kelas $(50,00 \%)$ memenuhi syarat. Menurut Keputusan Menteri Pendidikan Nasional RI Nomor 24 Tahun 2007 menyatakan bahwa batas minimum kepadatan hunian yang memenuhi syarat yaitu $2 \mathrm{~m}^{2}$ /orang.

Menurut teori dalam penelitian Rizka Tiara Vindrahapsari (2016) menyatakan bahwa penghuni dalam ruangan berpengaruh terhadap suhu, dan penyebaran bakteri dalam ruangan. Semakin banyak penghuni maka udara akan semakin panas, selain itu bakteri juga bisa terbawa oleh penghuni dan meneyebar ke udara sekitar ruangan sehingga mengkontaminasi udara ruangan. Keadaan di lapangan terdapat 6 ruang kelas $(50,00 \%)$ yang tidak memenuhi syarat, untuk itu perlu mengatur jumlah siswa yang diterima pada saat penerimaan peserta didik baru sehingga dapat mendapatkan ratio kepadatan hunian yang sesuai dengan persyaratan.

5. Perilaku Penghuni

Penilaian perilaku penghuni di 12 ruang kelas menggunakan kuisioner menunjukkan 3 ruang kelas $(25,00 \%)$ memiliki perilaku cenderung aktif, 7 ruang kelas $(58,30 \%)$ 
memiliki perilaku cenderung cukup aktif, dan 2 ruang kelas $(16,70 \%)$ memiliki perilaku cenderung tidak aktif.

Aktifitas yang dilakukan oleh penghuni ruangan akan berpengaruh pada energi/panas yang dikeluarkan dari tubuh, semakin tinggi aktifitas yang dilakukan maka semakin besar pula kecepatan metabolisme dalam tubuh sehingga semakin besar energi/panas yang dihasilkan.. Kehadiran manusia dapat mempengaruhi jumlah bakteri di dalam ruangan karena manusia merupakan salah satu sumber utama bakteri, dimana terdapat banyak bakteri di saluran pernafasan manusia yang dapat terlepas ke udara pada saat bercakap-cakap, batuk, bersin, dll.

\section{Angka Kuman Udara}

Tabel 3.5 Hasil Pengukuran Angka Kuman Udara

\begin{tabular}{cccc}
\hline No. & $\begin{array}{c}\text { Ruang } \\
\text { Kelas }\end{array}$ & $\begin{array}{c}\text { Angka Kuman } \\
\text { Udara }\left(\mathrm{CFU} / \mathrm{m}^{3}\right)\end{array}$ & Kategori \\
\hline 1. & 1A & 749,00 & TMS \\
\hline 2. & $1 \mathrm{~B}$ & 989,00 & TMS \\
\hline 3. & $2 \mathrm{~A}$ & 1548,00 & TMS \\
\hline 4. & 2B & 2517,00 & TMS \\
\hline 5. & $3 \mathrm{~A}$ & 3226,00 & TMS \\
\hline 6. & $3 \mathrm{~B}$ & 969,00 & TMS \\
\hline 7. & 4A & 1748,00 & TMS \\
\hline 8. & 4B & 2886,00 & TMS \\
\hline 9. & $5 \mathrm{~A}$ & 1927,00 & TMS \\
\hline 10. & $5 \mathrm{~B}$ & 1708,00 & TMS \\
\hline 11. & $6 \mathrm{~A}$ & 1348,00 & TMS \\
\hline 12. & $6 \mathrm{~B}$ & 609,00 & MS \\
\hline
\end{tabular}

Keterangan : TMS (Tidak Memenuhi Syarat) MS (Memenuhi Syarat)

Penelitian ini tidak sama dengan penelitian yang dilakukan oleh Vidyautami D.N bahwa hasil perhitungan jumlah koloni kedua ruangan (ruang kuliah non-AC dan ruang kuliah berAC) memenuhi baku mutu. Kondisi di lapangan, ruang kelas didesain dengan system ventilasi alami karenanya terdapat lubang ventilasi pada tiap kelas. Menurut teori dalam penelitian Alexandra Widyanareswari (2010) lubang ventilasi mengakibatkan adanya intrusi udara luar ruangan ke dalam ruangan, dengan adanya intrusi polutan dari luar ruangan yang turut mempengaruhi kualitas udara dalam ruangan. Tindakan pengendalian yang dapat dilakukan agar angka kuman udara di ruang kelas tidak melebihi batas maksimum, yaitu dengan menjaga kebersihan pengguna ruangan, memfasilitasi ruang kelas dengan ventilasi yang cukup untuk pergantian udara, serta dilakukan desinfeksi ruang kelas secara kontinyu.
7. Kecepatan Angin

Tabel 3.6 Hasil Pengukuran Kecepatan Angin

\begin{tabular}{cccc}
\hline No. & $\begin{array}{c}\text { Ruang } \\
\text { Kelas }\end{array}$ & $\begin{array}{c}\text { Kecepatan Angin } \\
(\mathrm{m} / \text { detik) }\end{array}$ & Kategori \\
\hline 1. & 1A & Tidak terdeteksi alat & TMS \\
\hline 2. & 1B & Tidak terdeteksi alat & TMS \\
\hline 3. & 2A & Tidak terdeteksi alat & TMS \\
\hline 4. & 2B & Tidak terdeteksi alat & TMS \\
\hline 5. & 3A & Tidak terdeteksi alat & TMS \\
\hline 6. & 3B & Terdeteksi 0,10 & TMS \\
\hline 7. & 4A & Tidak terdeteksi alat & TMS \\
\hline 8. & 4B & Tidak terdeteksi alat & TMS \\
\hline 9. & 5A & Tidak terdeteksi alat & TMS \\
\hline 10. & 5B & Tidak terdeteksi alat & TMS \\
\hline 11. & 6A & Tidak terdeteksi alat & TMS \\
\hline 12. & 6B & Tidak terdeteksi alat & TMS \\
\hline Keterangan : TMS (Tidak Memenuhi Syarat) & MS (Memenuhi Syarat) \\
\multicolumn{5}{c}{ Pada 12 ruang kelas dilakukan pengukuran }
\end{tabular}

kecepatan angin dengan menggunakan anemometer yang menunjukkan bahwa semua ruang kelas (100\%) tidak memenuhi syarat. Kecepatan angin yang memenuhi syarat berdasarkan Peraturan Menteri Kesehatan RI Nomor 48 Tahun 2016 yaitu berkisar 0,15-0,50 $\mathrm{m} /$ detik.

Menurut Givoni dalam Wulan Cendana Arum (2016, h.55) ada beberapa faktor yang saling berkaitan dan mendukung dalam menciptakan pertukaran udara yang baik pada suatu ruangan yaitu kecepatan angin di luar ruangan, suhu dan kelembapan udara di dalam dan luar ruangan, spesifikasi lubang ventilasi, alat penyedia / penunjang laju udara dalam ruangan. Menurut Peraturan Menteri Kesehatan RI No. 48 Tahun 2016 agar pertukaran udara dapat berjalan dengan baik, maka ruangan yang tidak menggunakan pendingin harus memiliki lubang ventilasi minimal $15 \%$ dari luas lantai dengan menerapkan system ventilasi silang.

\section{Arah Angin}

Tabel 3.7 Hasil Pengukuran Arah Angin

\begin{tabular}{ccc}
\hline No. & Ruang Kelas & Arah Angin $\left(^{\circ}\right)$ \\
\hline 1. & $1 \mathrm{~A}$ & 90 \\
\hline 2. & $1 \mathrm{~B}$ & 180 \\
\hline 3. & $2 \mathrm{~A}$ & 135 \\
\hline 4. & $2 \mathrm{~B}$ & 135 \\
\hline 5. & $3 \mathrm{~A}$ & 270 \\
\hline 6. & $3 \mathrm{~B}$ & 270 \\
\hline 7. & 4A & 225 \\
\hline 8. & 4B & 120 \\
\hline 9. & $5 \mathrm{~A}$ & 195 \\
\hline 10. & $5 \mathrm{~B}$ & 195 \\
\hline 11. & $6 \mathrm{~A}$ & 112 \\
\hline 12. & $6 \mathrm{~B}$ & 195 \\
\hline
\end{tabular}


Pengukuran arah angin menggunakan kompas dan tali di 12 ruang kelas menunjukkan arah angin 1 ruang kelas $(8,30 \%)$ bergerak $90^{\circ}$, arah angin 1 ruang kelas $(8,30 \%)$ bergerak $180^{\circ}$, arah angin 2 ruang kelas $(16,70 \%)$ bergerak $135^{\circ}$, arah angin 2 ruang kelas $(16,70 \%)$ bergerak $270^{\circ}$, arah angin 1 ruang kelas $(8,30 \%)$ bergerak $225^{\circ}$, arah angin 1 ruang kelas $(8,30 \%)$ bergerak $120^{\circ}$, arah angin 3 ruang kelas $(25,00 \%)$ bergerak $195^{\circ}$, dan arah angin 1 ruang kelas $(8,30 \%)$ bergerak $112^{\circ}$.

Menurut Tri Cahyono (2017, h.31) menyatakan bahwa arah angin dipengaruhi oleh tiga factor yaitu besarnya perbedaan gradient barometric, rotasi bumi dan kekuatan yang menahan (rintangan). Angin yang berkekuatan besar, makin sulit berbelok arah kecuali ada penghalang yang kuat. Bentuk bumi yang bulat menyebabkan pembelokan arah angin yang berbeda-beda.

\section{Frekuensi Pembersihan}

Penilaian frekuensi pembersihan di 12 ruang kelas dilakukan dengan kuisioner, frekuensi pembersihan dilakukan 1 kali/hari. Jika dibandingkan dengan Keputusan Menteri Kesehatan Nomor 1429 Tahun 2006 menunjukkan bahwa semua ruang kelas (100\%) memenuhi syarat, karena pembersihan ruang dan halaman sekolah harus dilakukan minimal 1 kali/hari.

Menurut Jensen dalam Wulan Cendana Arum (2016, h.17) untuk mengendalikan jumlah kuman udara dapat dilakukan dengan cara cleaning (pembersihan). Cleaning sangat penting di dalam mengurangi jumlah populasi kuman udara pada suatu ruang atau tempat, prinsipnya adalah menciptakan lingkungan yang tidak dapat menyediakan sumber nutrisi bagi pertumbuhan mikroba sekaligus membunuh sebagian populasi bakteri.

\section{Frekuensi Penggunaan Desinfektan}

12 ruang kelas SD Negeri Karangmangu dilakukan penilaian terhadap frekuensi penggunaan desinfektan dengan menggunakan kuisioner. Dari kuisioner tersebut menunjukkan bahwa semua ruang kelas menggunakan desinfektan sebanyak 0 kali/hari. Keputusan Menteri Kesehatan Nomor 1429 Tahun 2006 menyatakan bahwa pembersihan ruang dan halaman sekolah harus dilakukan minimal sehari satu kali menggunakan kain pel basah untuk menghilangkan debu dan menggunakan larutan desinfektan, sehingga dari 12 ruang kelas $(100 \%)$ tersebut, semuanya tidak memenuhi syarat.

Menurut Jensen dalam Wulan Cendana Arum (2016, h.17) menyatakan bahwa salah satu cara untuk mengendalikan jumlah kuman udara yaitu dengan cara desinfeksi. Desinfeksi adalah proses pengaplikasian bahan kimia dan biologi (desinfektan) terhadap peralatan, lantai, dinding atau lainnya untuk membunuh sel vegetative mikroba yang dapat diaplikasikan pada benda dan hanya berguna untuk membunuh sel vegetative saja, tidak mampu membunuh spora.

\section{b. Bivariate}

1. Hubungan Suhu dengan Angka Kuman Udara

Hasil analisis menunjukkan bahwa nilai $\mathrm{p}$ $=0,15$, maka dinyatakan terdapat hubungan yang tidak signifikan antara suhu dengan angka kuman udara. Nilai $\mathrm{R}=0,43$, maka tingkat hubungan suhu dengan angka kuman udara termasuk dalam kategori hubungan sedang. Nilai koefisien determinan sebesar 0,188 yang artinya suhu memberikan kontribusi terhadap perubahan angka kuman udara sebesar $18,00 \%$, sisanya $82,00 \%$ diakibatkan oleh variabel lain. Persamaan garis hubungan suhu dengan angka kuman udara menunjukkan $\mathrm{Y}=-6735,04+$ 299,55X.

Suhu mempengaruhi angka kuman udara tidak menentu, ada yang suhu semakin tinggi maka angka kuman udara semakin tinggi dan adapula yang suhu semakin tinggi angka kuman udara semakin tinggi. Fakta di lapangan menunjukkan bahwa semakin tinggi suhu, angka kuman udara semakin turun sehingga diindikasi mikroorganisme yang tumbuh adalah mikroorganisme mesofil dan mikroorganisme termofil.

2. Hubungan Kelembapan dengan Angka Kuman Udara

Analisis hubungan menunjukkan bahwa nilai $\mathrm{p}=0,54$, maka dinyatakan terdapat hubungan yang tidak signifikan antara kelembapan dengan angka kuman udara. Nilai $\mathrm{R}=0,19$, maka tingkat hubungan kelembapan dengan angka kuman udara temasuk dalam kategori hubungan lemah. Nilai koefisien determinan sebesar 0,03 yang dapat diartikan bahwa kelembapan memberikan kontribusi terhadap perubahan angka kuman udara sebesar 3,00\%, sisanya 97,00\% diakibatkan oleh variabel lain. Persamaan garis hubungan kelembapan dengan angka kuman udara menunjukkan $\mathrm{Y}=5766,83+(-53,98) \mathrm{X}$.

Penelitian ini tidak sama dengan penelitian yang dilakukan oleh Muhammad Syahrul Ramadhan (2018) dimana hasil penelitiannya menyebutkan bahwa kelembapan ruangan dengan keberadaan bakteri memiliki hubungan yang signifikan. Perbedaan penelitian ini dengan penelitian yang dilakukan oleh Muhammad Syahrul Ramadhan terletak pada 
lokasi, teknik sampling, jumlah sampel, dan analisis data. Lokasi penelitian Muhammad Syahrul Ramadhan terletak di ruang kuliah S1 FKM Unhas dengan menggunakan teknik sampling jenuh sebanyak 11 ruang kuliah, dan analisis data menggunakan uji Chi Square.

\section{Hubungan Pencahayaan dengan Angka Kuman Udara \\ Hasil analisis menunjukkan bahwa nilai $\mathrm{p}$} $=0,85$, maka dinyatakan terdapat hubungan yang tidak signifikan antara pencahayaan dengan angka kuman udara. Nilai $\mathrm{R}$ sebesar 0,06, sehingga tingkat hubungan pencahayaan dengan angka kuman udara termasuk dalam kategori hubungan sangat lemah. Nilai koefisien determinasi sebesar 0,004 yang artinya pencahayaan memberikan kontribusi terhadap perubahan angka kuman udara sebesar $0,40 \%$, sisanya $99,60 \%$ diakibatkan oleh variabel lain. Persamaan garis hubungan pencahayaan dengan angka kuman udara menunjukkan $\mathrm{Y}=1773,15+(-0,27) \mathrm{X}$.

Hubungan pencahayaan dengan angka kuman udara pada penelitian ini menunjukkan bahwa semakin tinggi tingkat pencahayaan maka angka kuman udara akan berkurang. Pommerville dalam Muhammad Syahrul Ramadhan (2018, h.67) mengemukakan bahwa pencahayaan yang dapat mempengatuhi bakteri adalah cahaya dari sinar matahari, pencahayaan dari sinnar matahari dapat menghambat pertumbuhan bakteri.

4. Hubungan Kepadatan Hunian dengan Angka Kuman Udara

Analisis hubungan menunjukkan bahwa nilai $\mathrm{p}=0,22$, maka dinyatakan terdapat hubungan yang tidak signifikan antara kepadatan hunian dengan angka kuman udara. Diperoleh nilai $\mathrm{R}$ sebesar 0,38 maka tingkat hubungan kepadatan hunian dengan angka kuman udara termasuk dalam kategori hubungan lemah. Nilai koefisien determinasi sebesar 0,14 dapat diartikan bahwa kepadatan hunian memberikan kontribusi terhadap perubahan angka kuman udara sebesar $14,00 \%$ dan sisanya $86,00 \%$ diakibatkan oleh variabel lain. Persamaan garis hubungan kepadatan hunian dengan angka kuman udara menunjukkan $\mathrm{Y}=2931,93+(-587,09) \mathrm{X}$.

Hasil penelitian ini sama dengan penelitian yang dilakukan oleh Citra Kusumawardhani Unika Putri (2018) dimana hasil penelitiannya menyebutkan bahwa tidak terdapat hubungan yang bermakna antara kepadatan ruang dengan angka kuman udara. Perbedaan penelitian ini dengan penelitian yang dilakukan oleh Citra Kusumawardhani Unika Putri adalah terletak pada lokasi, jumlah sampel 35, dan analisis data. Lokasi dari penelitian Citra Kusumawardhani Unika Putri terletak di rumah sakit dengan jumlah sampel dan uji Rank Spearman.

5. Hubungan Perilaku Penghuni dengan Angka Kuman Udara

Hasil analisis menunjukkan bahwa nilai $\mathrm{p}$ $=0,20$, maka dinyatakan terdapat hubungan yang tidak signifikan antara perilaku penghuni dengan angka kuman udara. Nilai $\mathrm{R}=0,39$ maka tingkat hubungan perilaku penghuni dengan angka kuman udara termasuk dalam kategori hubungan lemah. Nilai koefisien determinasi sebesar 0,156 yang artinya perilaku penghuni memberikan kontribusi terhadap perubahan angka kuman udara sebesar 15,00\%, sisanya $85,00 \%$ diakibatkan oleh variabel lain. Persamaan garis hubungan kepadatan hunian dengan angka kuman udara menunjukkan $\mathrm{Y}=$ $2717,25+(-495,32) X$.

Hasil penelitian ini sama dengan penelitian yang dilakukan oleh Didik Agus Nugroho, Budiyono, dan Nurjazuli (2016) yang menyebutkan bahwa tidak ada hubungan antara kondisi personal hygiene pasien dengan angka kuman udara. Perbedaan penelitian ini dengan penelitian Didik Agus Nugroho, Budiyono, dan Nurjazuli terdapat pada lokasi, populasi, sampel, dan analisis data. Lokasi penelitian yang dilakukan oleh Didik Agus Nugroho, Budiyono, dan Nurjazuli adalah di rumah sakit dengan populasi ruang rawat inap dan sampel rawat inap kelas tiga melati, sedangkan analisis data yang digunakan adalah uji chi-square.

\section{c. Multivariate}

Variabel yang paling signifikan mempengaruhi angka kuman udara adalah variabel suhu, kelembapan, dan pencahayaan dengan nilai $\mathrm{p}$ sebesar 0,09. Nilai $\mathrm{R}$ sebesar 0,72 sehingga tingkat hubungan suhu, kelembapan, dan pencahayaan termasuk dalam kategori hubungan kuat. Nilai koefisien determinasi sebesar 0,52 yang artinya suhu, kelembapan dan pencahayaan memberikan kontribusi terhadap perubahan angka kuman udara sebesar 52,00\%, sisanya 48,00\% diakibatkan oleh variabel lain. Persamaan garis menunjukkan $\mathrm{Y}=-52885,67+1132,62 \mathrm{X}_{1}+$ $313,39 \mathrm{X}_{2}+(-2,99) \mathrm{X}_{3}$.

Dalam penelitian ini dinyatakan bahwa variabel suhu, kelembapan dan pencahayaan mempunyai hubungan yang paling signifikan dengan angka kuman udara. Variabel lain yang tidak signifikan belum tentu tidak memberikan pengaruh terhadap angka kuman udara karena banyak faktor yang mempengaruhi kualitas udara dalam ruang. Menurut Tan Malaka dalam C R Candrasari dan J Mukono (2013) 
menyatakan bahwa intensitas pengaruh berbagai faktor yang dapat mempengaruhi lingkungan kerja tergantung lokasi dan proses yang ada.

\section{Simpulan dan Saran}

\section{a. Simpulan}

Rata-rata suhu di ruang kelas sebesar $28,11^{\circ} \mathrm{C}$, rata-rata kelembapan di ruang kelas sebesar $75,59 \%$, rata-rata pencahayaan di ruang kelas sebesar 320,45 lux, rata-rata kepadatan hunian di ruang kelas sebesar 2,12 $\mathrm{m}^{2} /$ orang, penilaian perilaku penghuni terdapat 2 ruang kelas tidak aktif, 7 ruang kelas cukup aktif, dan 3 ruang kelas aktif, rata-rata angka kuman udara di ruang kelas sebesar 1685,33 CFU/m ${ }^{3}$, rata-rata kecepatan angin sebesar 0,0083 , ratarata arah angin sebesar $176,83^{\circ}$, penilaian frekuensi pembersihan di ruang kelas menunjukkan semua ruang kelas memenuhi syarat dan penilaian frekuensi penggunaan desinfektan di ruang kelas menunjukkan semua ruang kelas tidak memenuhi syarat. Tidak terdapat hubungan yang signifikan antara suhu dengan angka kuman udara $(\mathrm{p}=0,159 ; \mathrm{R}=0,43$, $\mathrm{Y}=(-6735,04)+299,55 \mathrm{X})$ di SD Negeri Karangmangu. Tidak terdapat hubungan yang signifikan antara kelembapan dengan angka kuman udara $(\mathrm{p}=0,541 ; \mathrm{R}=0,19 ; \mathrm{Y}=5766,83+(-$ 53,98)X) di SD Negeri Karangmangu.Tidak terdapat hubungan yang signifikan antara pencahayaan dengan angka kuman udara $(p=0,853 ; \quad R=0,06 ; \quad Y=1773,15+(-0,27) X) \quad$ di SD Negeri Karangmangu.Tidak terdapat hubungan yangsignifikan antara kepadatan hunian dengan angka kuman udara $(\mathrm{p}=0,222$; $\mathrm{R}=0,38 ; \mathrm{Y}=2931,93+(-587,09) \mathrm{X})$ di SD Negeri Karangmangu.Tidak terdapat hubungan yang signifikan antara perilaku penghuni dengan angka kuman udara ( $\mathrm{p}=0,204 ; \mathrm{R}=0,39$; $\mathrm{Y}=2717,25+(-495,32) \mathrm{X})$ di SD Negeri Karangmangu.Terdapat hubungan yang paling signifikan antara suhu, kelembapan dan pencahayaan $(\mathrm{p}=0.09)$ dengan angka kuman udara. Serta menunjukkan persamaan garis $\mathrm{Y}=$ $-52885,67+1132,62 \mathrm{X}_{1}+313,39 \mathrm{X}_{2}+(-$ 2,99) $\mathrm{X}_{3}$

\section{b. Saran}

Perlu adanya ketersediaan ventilasi yang baik sehingga dapat mengakibatkan pertukaran udara yang baik pula di dalam ruang kelas, penambahan kipas atau bisa juga dengan exhauster, apabila kelembapan tinggi exhauster dapat menarik udara keluar dan juga sebaliknya apabila kelembapan rendah maka exhauster dapat menarik udara dari luar.

Sebaiknya di setiap ruang kelas perlu difasilitasi gorden untuk mengurangi pancaran sinar matahari yang masuk ke dalam ruang kelas serta penanaman pohon rindang disekitar ruang kelas, untuk ruang kelas $2 \mathrm{~A}$ dan $2 \mathrm{~B}$ merupakan ruang kelas yang paling rendah tingkat pencahayaanya dapat dibantu dengan cara penambahan lampu neon sebanyak 4 buah.

Perlu mengatur jumlah siswa yang diterima pada saat penerimaan peserta didik baru sehingga dapat mendapatkan ratio kepadatan hunian yang sesuai dengan persyaratan.

Perlu dilakukan pembersihan ruang kelas dengan menggunakan larutan desinfektan untuk menurunkan angka kuman udara.

Sebaiknya untuk peneliti lain dapat menganalisis jenis dan spesifikasi bakteri.

\section{DAFTAR PUSTAKA}

Alexandra Widyanareswari. 2010. Kualitas udara mikrobiologis ruang kelas studi kasus gedung perkuliahan A dan K FTUI. Skripsi. Depok : Fakultas Teknik Program Studi Teknik Lingkungan. https://anzdoc.com/queue/. Diakses pada 28 Februari 2019 pukul 01:11 WIB.

Aris Santjaka. 2011. Statistik Untuk Penelitian Kesehatan 1. Yogyakarta : Nuha Medika.

Aziz Alimul Hidayat. 2007. Metode Penelitian Kebidanan dan Teknik Analisis Data, Jakarta : Salemba Medika.

Cahyatri Rupisianing Candrasari dan J Mukono. Vol 7 No 1 2013. Hubungan kualitas udara dalam ruang dengan keluhan penghuni lembaga permasyarakatan kelas IIA kabupaten Sidoarjo. Surabaya : Departemen Kesehatan Lingkungan Fakultas Kesehatan Masyarakat Universitas Airlangga. http://journal.unair.ac.id/. Diakses pada 27 Februari 2019 pukul 23:50 WIB.

Citra Kusumawardhani Unika Putri. 2018. Faktor Lingkungan Fisik yang Berhubungan dengan Angka Kuman Udara di Ruang Rawat Inap Kelas I, II,dan III RST Wijayakusuma Purwokerto Tahun 2018. Skripsi. Purwokerto : Jurusan Kesehatan Lingkungan Politeknik Kesehatan Kemenkes Semarang.

D. Dwidjoseputro. 1989. Dasar-Dasar Mikrobiologi. Jakarta : Djambatan.

Desi Suwarsito Pratomo dan Erna Zuni Astuti. 2015. Analisis Regresi Korelasi antara Pengunjung dan Pembeli terhadap Nominal Pembelian di Indomaret Kedungmundu Semarang dengan Metode Kuadrat Terkecil. Semarang : Teknik Informatika Universitas 
Dian Nuswantoro. http://eprints.dinus.ac.id. Diakses pada 13 Maret 2019 pukul 14:34 WIB.

Devi Nur Vidyautami, Haryono Setiyo Huboyo, dan Mochtar Hadiwidodo. Vol 4, no. 1 2015. Pengaruh Penggunaan Ventilasi (AC dan Non AC) dalam Ruangan Terhadap Keberadaan Mikroorganisme Udara (Studi Kasus : Ruang Kuliah Jurusan Teknik Sipil Universitas Diponegoro). Semarang : Teknik Lingkungan Universitas Diponegoro. https://ejournal3.undip.ac.id/. Diakses pada 28 Februari 2019 pukul 02:19 WIB.

Didik Agus Nugroho. dkk. 2016. Jurnal FaktorFaktor Yang Berhubungan Dengan Angka Kuman Udara Di Ruang Rawat Inap Kelas III Rsud Dr. Moewardi Surakarta. Semarang : Jurnal Kesehatan Masyarakat (E-journal) FKM Universitas Diponegoro. https://media.neliti.com/. Diakses pada 21 Oktober 2018 pukul 23:34 WIB.

Direktorat Jenderal Pendidikan Dasar dan Menengah. 2018. Data Pokok Sekolah Dasar dan Menengah. Jakarta : Direktorat Jenderal Pendidikan Dasar dan Menengah. http://dapo.dikdasmen.kemdikbud.go.id/.

Diakses pada 21 Oktober 2018 pukul 01:24 WIB.

Esi Lisyastuti. 2010. Jumlah Koloni Mikroorganisme Udara Dalam Ruang dan Hubungannya dengan Kejadian Sick Building Syndrome (SBS) Pada Pekerja Balai Besar Teknologi Kekuatan Struktur (B2TKS) BPPT Di Kawasan Puspitek Serpong Tahun 2010. Tesis. Depok : Fakultas Kesehatan Masyarakat Universitas Indonesia. http://lib.ui.ac.id/. Diakses pada 21 Oktober 2018 pukul 23:31 WIB.

Hadita Deni Ayu Puspitasari. 2018. Pengaruh Perasan Daun Lidah Mertua (Sansevieria trifasciata prain) Terhadap Angka Kuman Udara Di Ruang Kelas R226, R221 dan R222 Jurusan Kesehatan Lingkungan Politeknik Kesehatan Kemenkes Semarang Tahun 2018. Skripsi. Purwokerto : Jurusan Kesehatan Lingkungan Politeknik Kesehatan Kemenkes Semarang.

Indah Denas Tiarawati. 2011. Kualitas udara mikrobiologis di fasilitas penjara dan resiko yang ditimbulkan (Studi kasus : Rutan Salemba). Skrispi. Depok : Fakultas Teknik Universitas Indonesia. http://lib.ui.ac.id/. Diakses pada 27 Februari 2019 pukul 00:06 WIB.
Indonesia, Menteri Kesehatan. 2006. Keputusan Menteri Kesehatan RI Nomor 1429 Tahun 2006 tentang Pedoman Penyelenggaran Kesehatan Lingkungan Sekolah. Jakarta : Menteri Kesehatan Republik Indonesia.

Indonesia, Menteri Pendidikan dan Kebudayaan, dkk. 2014. Peraturan Bersama Mendikbud Nomor 6/X/PB/2014, Menkes Nomor 73 Tahun 2014, Menteri Agama Nomor 41 Tahun 2014 Menteri Dalam Negeri RI Nomor 81 Tahun 2014 tentang Usaha Kesehatan Sekolah (UKS).Jakarta : Menteri Pendidikan dan Kebudayaan, Menteri Kesehatan, Menteri Agama, dan Menteri Dalam Negeri Republik Indonesia.

Indonesia, Menteri Kesehatan. Peraturan Menteri Kesehatan RI Nomor 48 Tahun 2016, tentang Standar Keselamatan dan Kesehatan Kerja Perkantoran. Jakarta : Menteri Kesehatan Republik Indonesia.

Indonesia, Menteri Pendidikan Nasional. 2007. Peraturan Menteri Pendidikan Nasional RI Nomor 24 Tahun 2007, tentang Standar Sarana dan Prasarana Sekolah Dasar/Madrasah Ibtidaiyah(SD/MI), Sekolah Menengah Pertama/Madrasah Tsanawiyah (SMP/MTs) dan Sekolah Menengah Atas/Madrasah Aliyah (SMA/MA). Jakarta : Menteri Pendidikan Nasional Republik Indonesia.

Indonesia, Pemerintah Republik Indonesia. 2014. Peraturan Pemerintah RI Nomor 66 Tahun 2014 tentang Kesehatan Lingkungan. Jakarta : Pemerintah Republik Indonesia.

Indonesia, Pemerintah Republik Indonesia. 1999. Peraturan Pemerintah RI Nomor 41 Tahun 1999 tentang Pengendalian Pencemaran Udara. Jakarta : Pemerintah Republik Indonesia.

Indonesia, Pemerintah Republik Indonesia. 2009. Undang-Undang Republik Indonesia Nomor 36 Tahun 2009 tentang Kesehatan, Jakarta : Pemerintah Republik Indonesia.

Indonesia, Pemerintah Republik Indonesia. 2003. Undang-Undang Nomor 20 Tahun 2003 tentang Sistem Pendidikan Nasional. Jakarta : Pemerintah Republik Indonesia.

Matin Arifudin. 2017. Tingkat Pengetahuan Kebersihan Lingkungan Sekolah Pada Siswa Kelas IV dan V SD Negeri Sambiroto 2 Kecamatan Kalasan Kabupaten Sleman. Skripsi. Yogyakarta : Universitas Negeri 
Yogyakarta.

https://eprints.uny.ac.id/.

Diakses pada 18 November 2018 pukul 19:48 WIB.

M Tahir Abdullah. dkk. 2011. JurnalLingkungan Fisik dan Angka Kuman Udara Ruangan di Rumah Sakit Umum Haji Makassar, Sulawesi Selatan. Makassar : Fakultas Kesehatan Masyarakat Universitas Hasannudin. http://journal.fkm.ui.id/. Diakses pada 17 Oktober 2018 pukul 20.38 WIB.

Muhammad Syahrul Ramadhan. 2018. Hubungan keberadaan bakteriologis udara terhadap kondisi ruangan di ruang kuliah mahasiswa S1 Fakultas Kesehatan Masyarakat Universitas Hasanuddin. Skripsi. Makassar : Departemen Kesehatan Lingkungan Fakultas Kesehatan Masyarakat Universitas Hasanuddin. http://digilib.unhas.ac.id/. Diakses pada 27 Februari 2019 pukul 10:51 WIB.

Nadia. 2012. Hubungan Pelaksanaan Program Usaha Kesehatan Sekolah Terhadap Perilaku Hidup Bersih dan Sehat Pada Siswa SDN 13 Seberang Padangutara Tahun 2012. Skripsi. Padang : Universitas Andalas. http://repo.unand.ac.id/. Diakses pada 20 Oktober 2018 pukul 22:29 WIB.

Nayla Kamilia Fithri, Putri Handayani, dan Gisely Vionalita. 2016. Faktor-faktor yang berhubungan dengan jumlah mikroorganisme udara dalam ruang kelas lantai 8 Universitas Esa Unggul. Jakarta : Fakultas Ilmu-ilmu Kesehatan Universitas Esa Unggul. http://digilib.esaunggul.ac.id/. Diakses pada 27 Februari 2019 pukul 22:52 WIB.

Ricki M Mulia. 2005. Kesehatan Lingkungan. Yogyakarta : Graha Ilmu.

Rina Febriani. 2017. Pengaruh Ion Plasma Terhadap Penurunan Angka Kuman Udara DI Ruang Kelas Gedung R2 Jurusan Kesehatan Lingkungan Politeknik Kesehatan Kemenkes Semarang Tahun 2017. Skripsi. Purwokerto : Jurusan Kesehatan Lingkungan Politeknik Kesehatan Kemenkes Semarang.

Rizka Tiara Vindrahapsari. 2016. Kondisi fisik dan jumlah bakteri udara pada ruangan AC dan Non AC di Sekolah Dasar (Studi Sekolah Dasar Sang Timur Semarang). Skripsi. Semarang : Fakultas Kesehatan Masyarakat Universitas Muhammadiyah Semarang. http://repository.unimus.ac.id/. Diakses pada 27 Februari 2019 pukul 18:52 WIB.

Rr Sumiyati. 2015. Tingkat Pemahaman Tentang Kesehatan Lingkungan Sekolah Pada Siswa Kelas IV Dan $V$ SD Negeri Kembang Malang, Panjatan Kulon Progo DIY. Skripsi.Yogyakarta : Fakultas Ilmu Keolahragaan Universitas Negeri Yogyakarta. https://eprints.uny.ac.id/. Diakses pada 18 November 2018 pukul 23:55 WIB.

Singgih Santoso. 2015. Menguasai Statistik Parametrik. Jakarta : PT Elex Media Komputindo.

Sri Ayu Suhra. 2016. Pengaruh Fasilitas Belajar Terhadap Hasil Belajar Siswa Pada Mata Pelajaran Ekonomi Madrasah Aliyah DDI Wanio Kab.Sidrap. Skripsi. Makassar : Universitas Negeri Makassar. http://eprint.unm.ac.id/. Diakses pada 19 November 2018 pukul 22:34 WIB.

Taufik Nurohim. 2016. Pengaruh Penggunaan Ion Plasma dengan Penurunan Jumlah Angka Kuman Udara pada Instalasi Ruang Gawat Inap I di RSUD Margono Soekarjo Purwokerto Tahun 2016. Skripsi. Purwokerto : Jurusan Kesehatan Lingkungan Politeknik Kesehatan Kemenkes Semarang.

Tri Cahyono. dkk. 2017. Modul Praktik Laboratorium Mata Kuliah Penyehatan Udara. 2017. Purwokerto : Jurusan Kesehatan Lingkungan Politeknik Kesehatan Kemenkes Semarang.

Tri Cahyono. 2017. Penyehatan Udara Edisi I. Yogyakarta : ANDI.

Vita Wiana Budi Cahya. 2016. Faktor-Faktor yang berhubungan dengan keberadaan bakteri udara di ruang kelas (studi di yayasan mataram semarang). Skripsi. Semarang : Fakultas Kesehatan Masyarakat Universitas Muhammadiyah Semarang. http://repository.unimus.ac.id/. Diakses pada 27 Februari 2019 pukul 17:18 WIB.

Wulan Cendana Arum. 2016. Pemakaian Daun Jeruk Nipis (Citrus aurantifolia) Terhadap Angka Kuman Udara Ruang Kelas R221 Jurusan Kesling Purwokerto Tahun 2016. Skripsi. Purwokerto : Jurusan Kesehatan Lingkungan Politeknik Kesehatan Kemenkes Semarang. 